\title{
Time for Punishment with Subjectivity: Study Philosophy of Law
}

\author{
Aditya Yuli Sulistyawan \\ Diponegoro University, Semarang, Indonesia \\ e-mail: aditya_yuli@yahoo.co.id
}

\begin{abstract}
Dominasi positivisme hukum dalam pemikiran dan penegakan hukum adalah suatu kenyataan. Saintisme ilmu hukum menghadirkan hukum yang dikonsepsikan sebagai sesuatu yang eksis secara indrawi, berikut sifatnya yang lugas, rasional, dan objektif. Hukum senantiasa diminta terselenggara secara objektif. Objektivitas dilakukan dengan membebaskan pikiran subjek terhadap realitas hukum yang sudah eksis menjadi objek. Oleh karenanya, berbagai kasus-kasus hukum seperti kasus Nenek Asyani, Nenek Rasminah, Nenek Minah dan lain-lain, menjadi hal yang mudah dibuktikan sebagai pelanggaran hukum karena merupakan pelanggaran terhadap teks pasal undang-undang. Cara berhukum yang seperti itu, saat ini mulai menjadi perhatian masyarakat luas. Maka, ketika objektivitas mulai dipertanyakan, saat itulah sesungguhnya subjektivitas meminta mulai dipertimbangkan - dan hal ini akan dapat dijelaskan [hanya] dalam telaah filsafat hukum, khususnya kajian paradigmatik. Tulisan ini akan membahas perihal kemungkinan dilakukannya subjektivitas dalam berhukum, yang akan dipaparkan dalam kajian paradigmatik.
\end{abstract}

Keywords: subjektivitas; paradigma; positivisme hukum; filsafat hukum 
The dominance of legal positivism in thought and law enforcement is a reality. Saintism of legal science presents a law that is conceptualized as something that exists in sensory terms, along with its straightforward, rational, and objective nature. Law is always requested objectively. Objectivity is done by freeing the subject's mind to the legal reality that already exists as an object. Therefore, various legal cases such as the case of Asyani, Rasminah, Minah and others, are things that are easily proven as violating the law because it is a violation of the text of the article of law. Such a way of law, is now starting to become a public concern. So, when objectivity begins to be questioned, that's when the real subjectivity of asking begins to be considered - and this will be explained [only] in the study of legal philosophy, especially paradigmatic studies. This paper will discuss the possibility of subjectivity in law, which will be presented in the paradigmatic study.

Keywords: subjectivity; paradigm; positivism of law; philosophy of law

\section{Introduction}

The beginning of the writer's confusion regarding the title above departs from personal experience when dealing with 'law' at the beginning of becoming a lecturer. The experience occurred around 2009, when the writer who was currently suffering from an ankle injury due to penchant sports, wanted to teach a course on campus.

That afternoon, a few days after suffering an injury, the writer had to teach in a classroom located some distance from the campus entrance. Go to the room by piggybacking on a friend's motorcycle, and intend to be delivered right in front of the classroom, so that the limping feet do not get exhausted to the location where the teaching is. But that hope seemed to vanish, when passing through the main gate, a campus security guard stopped our motorbikes, then expressly forbade us from entering the campus area by motorcycle.

This is the rule, sir," said the man to the writer who happened to know me as a lecturer. I then replied, "sorry sir, I want to teach in Room C.102 and my foot is injured". However, instead of allowing entry, this security guard actually fetched a few pieces of paper at his post. Strictly speaking, the 
security guard said, "This is the regulation, sir. In this regulation motorcycle vehicles may not enter the campus area".

Grateful, shortly afterwards, this debate soon ended after another security guard came to us. He then said "Oh Pak Adit, would you like to teach, sir? Please go to the classroom, sir! "Shortly after giving thanks and entering the campus area, the writer had looked back when the two security guards were arguing about what had just happened. However, whatever it is, finally the writer can carry out the task, namely teaching.

After that incident, the writer continued to ponder what really happened regarding the 'lawful' way of the two security guards in my case. Even though the level is local scale, on campus, the actual way of law (read: the practice of applying the law) of the two security guards in the story is a picture of a wider way of law, even in the context of the state. The debate about objectivity contra subjectivity in the way of law in this country is not something simple to understand. Moreover, the determination of legal positivism is already rooted in the world of law enforcement. Therefore, objectivity becomes difficult to negotiate.

The glory of legal positivism then presents the reality of law enforcement that disturbs human values and conscience. Various law enforcement cases occurred, such as theft of teak wood owned by Perhutani by Asyani's grandmother in Situbondo; the theft of six plates by Grandma Rasminah in Ciputat; the theft of a watermelon by Kolil and Basar Suyanto in Kediri; theft of flip-flops by a child with the initials AAL in Palu; the theft of the kapok fruit by Manisih in Batang; or the theft of three cocoa beans by Grandma Minah in Banyumas, as well as many other similar cases, often seizing the attention of the community as well as empathy.

For most law learners [including all law practitioners], law has a concept that seems singular. Law is nothing but drafted as a set of written regulations, made by the competent institution, strictly binding because it is equipped with sanctions for those who break them. Such understanding is not wrong, higher education in law even leads them to embrace a Bachelor of Laws who believe in the truth of such a law.

Understanding of law that dominates law enforcement lessons and practices is the influence of the school of legal positivism. Like the 'menu' presented in legal education, law is then created in its almost uniform 
definition. The intellectuals in the field of law are then convinced that the nature of the law is the regulation itself, along with its objective nature. This then becomes the ontological conviction of law practitioners in seeing the reality called law. The study and application of law is always certain that they will just do it straightforwardly, rationally, and objectively, without further questioning it.

Through this understanding, it is natural that the law does not care about 'the weak', 'the poor', 'the elderly' and others as described in the cases above.

The assumption that they are supposed to be objective is increasingly nurtured by the fact that they are rarely asked to consider further the legal material they are involved in and any effort made to better understand the human consequences of the law is immediately seen as futile (Indarti 2001: 9). This paper will not discuss the characteristics of legal education as the author began to explain above, but will explore further the objectivity of the law that should be reconsidered as a nature of law, consistent with the title that the writer adopts.

\section{Legal Objectivity Journey}

Objectivity is the nature of law as believed in the school of legal positivism. Departing from efforts to 'ensure' social science [including science of law] as exact science, positivism was born as an answer to solve the problems that occurred at that time. Beginning in the 18th century, admiration for the achievements of science as a natural science and its applied results gave birth to increasingly prosperous producing industries. Since then the French intelligence circles have been suspected of thinking towards the scientist movement (Wignjosoebroto 2012) to study and find solutions to social problems.

It was Auguste Comte (1798-1857), a polytechnic school graduate who was later better known in many circles as a philosopher, who through his book titled Course De La Philosophie Positive explores the idea that human society can be studied, both in static and dynamic conditions, by the method which has been known in the natural and life sciences. Scientism (which came to be known as positivism) extended to all fields of science, including social and humanities. Law also does not miss using the positivism model. 
A very prominent example is Hans Kelsen with Reine Rechtslehre. Law is the logical arrangement of the rules that apply to a particular place and the science of law is the science of those rules. The essence of Kelsen's Theory (Suteki 2012) is as follows:

The aims of a theory of law, as of any science, is to reduce chaos and multiciplity to unity;

1) Legal theory is science, not volition. It is knowledge of what the law is not what the law. The law is a normative not natural science;

2) Legal theory as a theory of norms is not concerned with the effectiveness of legal norms;

3) A theory of law is formal, a theory of the way of ordering, changing contents in a specific way.

The development of the philosophy of positivism that emerged since the 18th century did not cease to exert influence in legal thinking until now. The law is demanded to be something real in the middle of sensory objective nature. The law is interpreted as something that exists outside of humans, a set of written rules that are required to apply objectively. As a consequence of its nature, law (in the thought of legal positivism) must be implemented as the object wishes. Because the law has become something that exists (as an object), the administration of law must get rid of the will of the subject, releasing the subjectivity of human beings as the party who operates the law. Value free and context free are properties that are also required to be fulfilled in carrying out the objective law. Therefore, law enforcement starts to feel its 'rigidity', when all violations of the law are returned only to violations of article texts alone.

In modern life and civilization, law even far outperforms other forms of social life. Therefore, the sharpness and clarity and ability to force obeyed, then the law is a form of par excelence society. Due to its very sharp and penetrative shape, since the emergence of modern law there has been a quiet revolution in the world. Since then, the world has been sharply divided into two, namely the legal world and the social world (Prasetyo and Barkatullah 2009: 196).

The concept of law that is streamed by legal positivism presents a legal figure in such an objective manner, available in the meaning conveyed by the writings of the regulation as an independent object. The law is also a 
closed logical system, which means regulations can be deducted from applicable laws, without needing to seek guidance from social, political and moral norms. The characters include, R. von Jhering and John Austin.

Understanding the concept of law as delivered by the school of legal positivism to the present sufficient to color the world of law enforcement in Indonesia. That means, many of the legal practitioners are those who agree with such legal concepts. The implication is that in a rule of law such as Indonesia, the public seems to demand that the legal certainty be upheld, while demanding that objectivity be upheld above all. Those who are guided by such understanding become the ones who always agree that everything that is objective is positive, while the subjective is wrong, especially when speaking in the context of law enforcement.

In this matter, the author is reminded of one of the advertisements of one political party in this country some time ago, especially just before the 2014 election. Ads that attract the attention of the author, not only because of the frequent intensity of their broadcasts on television media, but also the advertising substance delivered . The ad sounds more or less like this: 'The law should be blind. He must not see the poor and the rich. The law must be objective, fair to anyone ...'

The advertising material as the writer said above seems to be something that is only natural. In legal positivism, it is certainly understandable if the statement is an ideal condition regarding the desired law. That means, this statement confirms that the law should be implemented with a strict nature, not in favor of anyone. Once a rule determines that something is declared unlawful, the offender must be punished, without exception.

This shows the nature of legal positivism, which is brought about by the logic of causation. This logic also builds firmness about the nature of objectivity that must always be upheld. The problem is, objectivity which is 'demanded' by legal positivism, is always inconsistent in the stance of their thinking. Ideal objectivity is often conveyed to require the law to be enforced 'as is' according to the text. While in other situations, they also 'flock' to talk about conscience into understanding a legal reality, a doubt that indicates inconsistency. 


\section{Objectivity vs Subjectivity: An Uncertain Judgment}

Law enforcement that holds true to objectivity then slowly starts to waver. For example, when in many cases the mass media raised a situation that expected objectivity to be upheld in law enforcement. But not in criminal cases committed by 'the poor', 'the weak', 'the old' or others who often seize the attention of the community as well as empathy, such as the cases experienced by Asyani's grandmother, Minah's grandmother, and others . Inconsistency can be seen in how the public (shown by the mass media) wants the perpetrators of such crimes not to be severely punished, even if they can be released.

Objectivity seems to be one thing that is enforced by law enforcement, while subjectivity is 'disturbing enough' there. On the one hand, the legal community who believe in legal positivism requires objective legal enforcement. But on the other side, they also cannot avoid that there is subjectivity which is often present in seeing the entry into force of the law. If they are firm in their beliefs about objective law, surely there is no need for a reaction if the perpetrators of the theft are punished through the verdict of the judges because it can clearly be proven to violate Article 362 of the Criminal Code. In fact, a number of actions and comments have arisen incessantly, disagreeing with such legal actions.

Examples of these cases show how subjectivity departing from the conscience or human values permeates human thought, which becomes difficult to avoid.

On many occasions, Professor of Diponegoro University Satjipto Rahardjo in various scientific performances stated that law enforcement is very much determined by the people themselves. Somewhat jokingly, a judge's breakfast, even determines the decisions he makes in court. Even though it was delivered in a joking atmosphere, actually there is something we can think of from what Satjipto Rahardjo said.

It can be felt that true subjectivity can emerge from a law enforcer, even the breakfast menu eaten by a judge can form a different inner atmosphere, something which then influences the decisions he makes. 
In fact, if the law must be objectively enforced, then the position of the object (in this case is a rule) must be outside of its human subject. That means, whatever the conditions that affect the subject, then a legal reality out there (read: written rules) does not change. In other words, objective law requires a condition that is not affected by the condition of the observer's subject.

For law enforcers, we can also witness doubt about objectivity in law. For example, when a judge starts to use his 'feelings' when handling a case. The Chief Judge of the Assembly in the case of Grandma Minah at the time, even had to read the verdict against Grandma Minah while holding back tears, was unable to decide on Grandma Minah's guilty (at least based on written legal texts).

For the writer, who is guided in a paradigm (Indarti 2010:16) that is not positivism, the specifics are also not adherents of the legal positivism school, the objective nature that follows the concept of law as di'imani 'those who adhere to the legal positivism is something that is impossible to imagine. The big question then is, is objectivity possible? While humans (who run the law) as subjects are very close to their subjectivity.

\section{Punishing with Subjectivity: Study Philosophy of Law}

The description of objectivity vs. subjectivity in law as mentioned above is not easy to understand. Therefore, this paper offers his study in the study of legal philosophy as an effort to dismiss our mutual doubts in understanding the above problems. Philosophical study is needed because philosophy promises answers to all problems to the final consequences with the aim of discovering their nature (Wiramihardja 2007).

The study of legal philosophy that the author uses as a tool to answer the above problematics is to use paradigmatic studies as a foundation for new thinking in philosophy. As one of the limits of understanding of the paradigm conveyed by E.G. Guba and Y.S. Lincoln, the paradigm is part of an overarching philosophy. Therefore, the paradigmatic explanation is nothing but an explanation from philosophy, especially because the questions in the paradigm understood by E.G. Guba and Y.S. Lincoln is 
a question of philosophy itself namely ontology, epistemology, and methodology.

The following table presents a set of basic beliefs 4 (four) main paradigms according to E.G. Guba and Y.S. Lincoln for us to use in understanding the issue of objectivity and subjectivity in law (Indarti, 2010: 18):

Table 1. Basic Belief Set of 4 (four) Main Paradigms

\begin{tabular}{|c|c|c|c|c|}
\hline Question & $\begin{array}{l}\text { Positivi } \\
\text { sm }\end{array}$ & $\begin{array}{c}\text { Postpositiv } \\
\text { ism }\end{array}$ & $\begin{array}{l}\text { Critical } \\
\text { Theory }\end{array}$ & \begin{tabular}{|} 
Konstruktivism \\
e
\end{tabular} \\
\hline \multirow[b]{3}{*}{ Ontologi } & $\begin{array}{c}\text { Naive } \\
\text { Realism: }\end{array}$ & \multirow[t]{2}{*}{$\begin{array}{c}\text { Critical } \\
\text { Relaism : }\end{array}$} & \multirow[t]{2}{*}{$\begin{array}{l}\text { Realisme } \\
\text { Historis : }\end{array}$} & Relativism : \\
\hline & external & & & \multirow[b]{2}{*}{$\begin{array}{l}\text { compound and } \\
\text { diverse realities, } \\
\text { based on social- } \\
\text { individual, local } \\
\text { and specific } \\
\text { experiences. }\end{array}$} \\
\hline & $\begin{array}{c}\text { reality, } \\
\text { objective, } \\
\text { real, and } \\
\text { understa } \\
\text { ndable. }\end{array}$ & $\begin{array}{c}\text { external, } \\
\text { objective, } \\
\text { and real } \\
\text { realities } \\
\text { that are } \\
\text { understood } \\
\text { imperfectly } \\
\text {. }\end{array}$ & $\begin{array}{l}\text { virtual' } \\
\text { realities } \\
\text { formed by } \\
\text { social, } \\
\text { political, } \\
\text { cultural, } \\
\text { economic, } \\
\text { ethnic and } \\
\text { 'gender' } \\
\text { factors. }\end{array}$ & \\
\hline
\end{tabular}




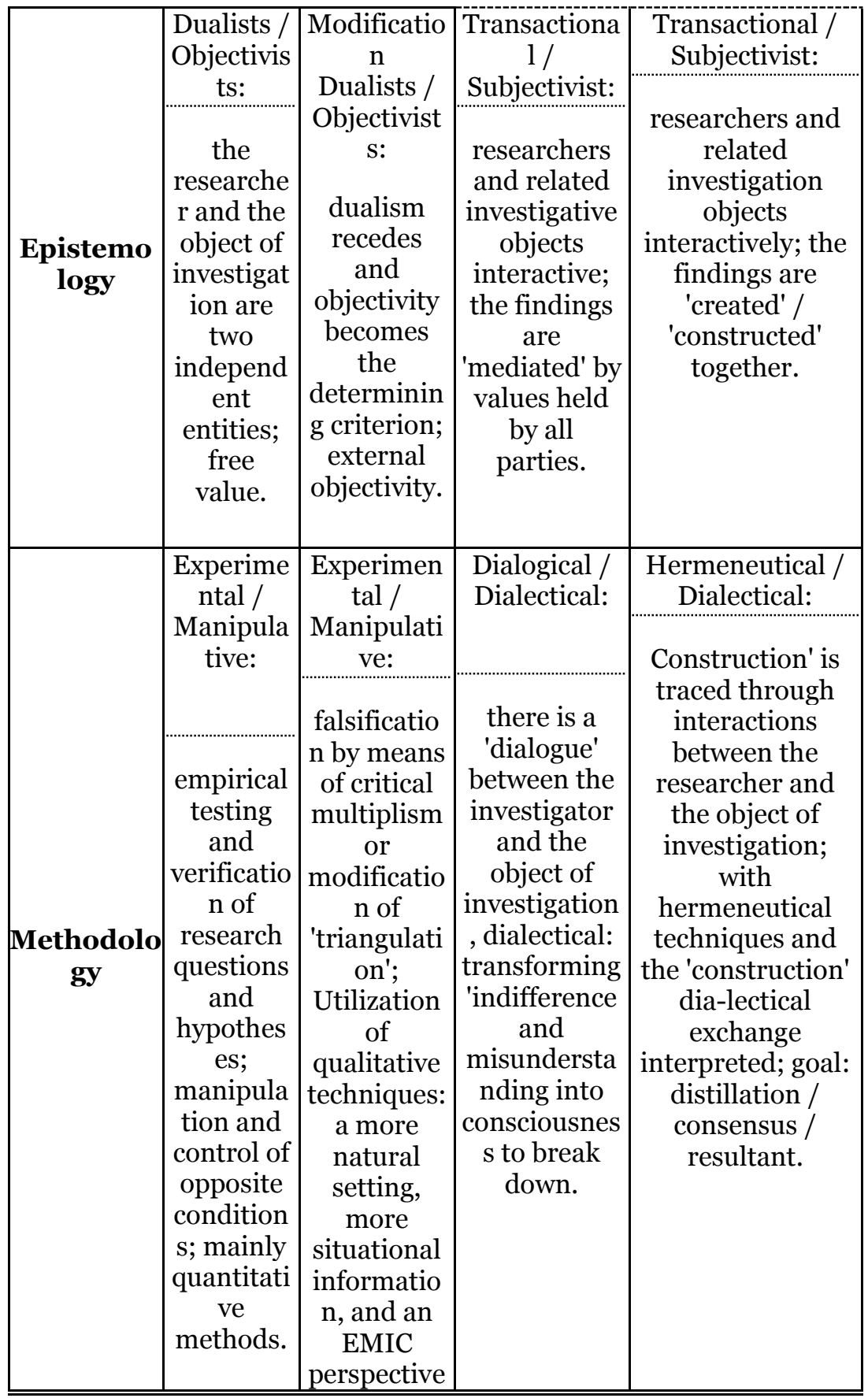




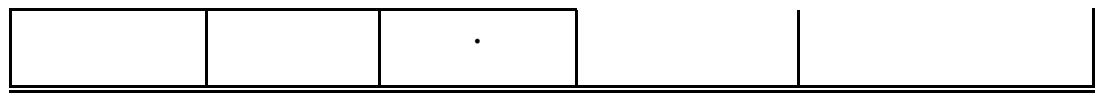

Sources: Guba and Lincoln (1994)

Paradigmatic explanations regarding objectivity and subjectivity have been answered in the table as presented above. Thus it should be understood that objectivity is a characteristic of the positivism paradigm, as well as post-positivism (in the modifications that have been made). Through understanding this paradigm, the word objective appears as the nature of reality in the ontology of the positivism paradigm, including the ontology of the post-positivism paradigm.

Ontology is a question about how the shape and nature of reality, along with what can be known from it (Indarti 2010: 18). Through ontology questions, the positivism paradigm asks that reality be entirely objective, while the post-positivism paradigm sees that reality must still be objective, but there is a critical meaning made by the subjects / adherents of the paradigm, so that the meaning of reality becomes not entirely objective, there begins to be subjectivity. included in how he understands reality.

Therefore, if the reality in question is the reality of law, then the law must be implemented as the will of its object (objective according to the positivism paradigm). While in the post-positivism paradigm, law is objective, but also allows criticism to be understood by including subjectivity (to a limited extent).

Based on the understanding built by the positivism paradigm, objectivity is a 'definite' nature of law. Legal certainty is given precisely because the law is left definite in its manifestation as an object (so it is objective) that is real and written, to which the law also becomes something determinant.

Besides being the nature of the ontology paradigm positivism and post positivism (although the objectivity is different in the two paradigms), the word objective also appears in the epistemological question answers (Indarti 2010: 18) in the positivism and post-positivism paradigms. It is stated that the epistemology of the positivism paradigm is dualist / objectivist, which means that adherents / holders and observational / investigative objects are two independent entities; free of value and free of 
bias. If this is contextualized in legal reality, then the subject / adherent must be detached to the legal reality (read: regulations), the two must not influence each other and also do not depend on each other. Whereas in the post-positivism paradigm, the answer to the question of epistemology is the modification of the dualist / objectivist.

This means that objectivity continues to be done even though the distance between the subject and the object (reality) has begun to recede, because there is criticism done. The description of the paradigm explanation of objectivity and subjectivity has been shown very well by E.G. Guba and Y.S Lincoln. Thus, it should be understood that the problem of objectivity and subjectivity turns out to be paradigmatic. Even through paradigms, we become perfumes that objectivity is a trait that overshadows those who paradigm positivism and post-positivism only. On the other hand, those who are guided by the critical theory paradigm et al. and constructivism is guided by subjectivity in their understanding of the 'world'.

Therefore, the truth that guides every person in this world is very dependent on the paradigm that he believes in, so the horizon is opened that thinking in this world is indeed not the same. Each must be understood according to the paradigm, including one's belief in objectivity or subjectivity which influences him to see reality, including the law.

However, considering that humans are subjects who continue to think and are close to their subjectivity, then objectivity in the style of positivism paradigm becomes impossible, except when law enforcement is carried out by law enforcement robots or if there are currently law enforcement agencies acting as' mouthpieces of the law just invite. Therefore, in this increasingly complex realm of life, subjectivity is an important part that should be included in all contextual actions, not all texts. When positivism as a school or also as a paradigm has begun to be questioned because of its failure to overcome the problem, then let's move to use subjectivity, both in terms of limited (post-positivism paradigm) or based on the full subjectivity (paradigm of critical theory and constructivism).

Before ending this paper, the writer will invite the reader back to the story that the writer experienced as the writer explained at the beginning. The author's anxiety about the different ways of judging the two security 
guards has actually been answered through this paradigmatic study. At least the authors are grateful to have found the answer in the world of legal philosophy, through its paradigmatic study. The objectivity and subjectivity seen in how the two security guards take the law is a very natural thing to happen in the differences in the world view of humans who are guided by different paradigms. Then, an examination of this will depend on us, whether we are adherents of a paradigm based on objectivity or subjectivity, including those based on texts or based on context.

\section{Conclusion}

Legal positivism as school in the science of law has an extraordinary influence on the life of law in the world, including in Indonesia. Worship of the principle of legal certainty, making law in such a way is the only guideline that must be held objectively. As a result, rigidity occurs when various legal issues are always resolved without empathy and what they are, depending on the legal text alone, not the context.

Therefore, legal cases such as those experienced by Grandma Asyani, Grandma Minah, and others can easily enter the realm of law. At that time, law enforcers, even the wider community felt the doubts in the law. Instead of wanting the law to be carried out objectively, society begins to include empathy, conscience, and such a sign that subjectivity is beginning to enter our realm of thought.

This is where the study of legal philosophy through its paradigmatic study is needed to explain this. That in fact we are starting to leave the objective way of law alone is a necessity. At least through the paradigm, we can understand that the objectivity upheld by the positivism paradigm is not the only guideline of thinking, there is still a post positivism paradigm, critical theory and constructivism which actually starts to involve human subjectivity.

Through this paradigm shifting, the law will lead to a more humanistic nature, because it involves humans as the organizer of the law. Therefore, the authors invite all law learners (academics and law enforcers) to start judging with subjectivity (in a paradigmatic framework). It's time to punish with subjectivity! [w] 
Aditya Yuli S, Time For Punishment with Subjectivity... 
Aditya Yuli S, Time For Punishment with Subjectivity...

\section{Noted:}

Scientism is a philosophical understanding (ism) that believes in the truth of the statement, that true human knowledge can only be obtained through a scientific method.

The paradigm is interpreted as a main philosophical system, parent, or umbrella which includes ontology, epistemology, and certain methodologies that cannot be exchanged so easily, which represent their adherents to the basic setbelief that attaches adherents to certain world views, along with the ways in which the world must be understood and studied, and guide every thought, attitude, word and deeds of its adherents.

Epistemological Question is a question about the nature of the relationship between individuals or groups of people with the environment or everything that is outside themselves, including what they can know. 


\section{BIBLIOGRAPHY}

Indarti, Erlyn. 2001. Menjadi Manusia Merdeka: Menggagas Paradigma Baru Pendidikan Hukum untuk Membangun Masyarakat Madani. Orasi Ilmiah yang disampaikan pada Dies Natalis ke-44 Fakultas Hukum Undip Semarang.

Indarti, Erlyn. 2010. Diskresi dan Paradigma: Sebuah Telaah Filsafat Hukum, Pidato Pengukuhan sebagai Guru Besar Filsafat Hukum pada Fakultas Hukum Undip Semarang, 2010.

Prasetyo, Teguh and Barkatullah, Abdul Halim. 2009. Ilmu Hukum dan Filsafat Hukum. Yogyakarta: Pustaka Pelajar.

Rahardjo, Satjipto. 2009. Penegakan Hukum: Suatu Tinjauan Sosiologis. Yogyakarta: Genta Publishing.

Suteki. 2012. Perkembangan Ilmu Hukum dan Implikasi Metodologinya. Makalah disajikan dalam Kongres Ilmu Hukum Indonesia yang diselenggarakan Fakultas Hukum Undip Semarang.

Wignjosoebroto, Soetandyo. 2012. Logika Saintisme untuk Ilmu Sosial dan Ilmu Hukum. Makalah disajikan dalam Kongres Ilmu Hukum Indonesia yang diselenggarakan Fakultas Hukum Undip Semarang.

Wiramihardja, Sutardjo A. 2007. Pengantar Filsafat. Bandung: PT Refika Aditama. 